under a broken shelf of the same, we found a portion of a human lower $\mathrm{jaw}$, together with a buman calcaneum. These latter remains from their position may be of the date of the worked flints, or they may be of any date greater or less than a few hundred years since.

The determination of the bones is due to Mr. Sanford.

TenBy : August 22, 1865 .

H. H. WINWOOD.

\title{
GLACIATION IN DEVON AND ITS BORDERS.
}

To the Editor of the Geological Magazine.

Sir,-I do not know whether anything has been published about ice-marks on the rocks of Exmoor, Dartmoor, or the other hills of the West of England. Perhaps, therefore, you will allow me to put on record a case of glaciation which I met with yesterday, as striking as any in the Killarney or Glengariff country in the southwest of Ireland. It is on the banks of the river Exe, about a mile and a half north-east of this little town, and about a quarter of a mile north of the ruins of Barlynch Abbey. The Exe runs rapidly down a beautifully wooded glen some 400 feet deep, and makes a sharp turn at the point indicated, where a mass of hard grits in the upper part of the true Old Red Sandstone juts out to the west, dipping south, and showing a steep little escarpment looking north up the valley. At the extreme point of this crag, where the valley is contracted to a quarter of its usual width, part of the face of the rock, 20 yards long and 20 feet high, looking up the river, is grooved, polished and scratched in parallel lines, nearly horizontal, but slightly inclined towards the bed of the river. It looks like a gigantic cornice-moulding, some of the more prominent ribs about 2 or 3 feet apart, others only 6 or 8 inches, but all undercut with a sharp symmetrically-rounded fluting to a depth of from 3 to 4 inches. The surfaces between the most prominent cornices are more slightly fluted, with lesser ribs, and the whole smoothed over with parallel rubbing-marks, exactly as may be seen at the sides of a modern glacier wherever a projecting crag intrudes itself into its course.

The absence of anything like boulder-clay, and the rarity of fartransported boulders, are circumstances in which this district also resembles the Killarney and Glengariff country, as well as in the identity of the rocks and character of the scenery.

Dulvarton: Sept. 19.

J. Beete Jukes.

\section{PRIMARY AND SECONDARY GLACIAL STRIA. \\ To the Editor of the Geological Magazine.}

SIR,-It is rather remarkable that none of the writers on Glacial Phenomena have mentioned Primary and Secondary sets of Striæ as having been observed in the localities of which they have given descriptions; and that they do not occur would appear to me rather remarkable, as in all the places in Ireland that $I$ have carefully examined I found them.

The Primary Strice and Grooves in this country have a general 
bearing of about NNE. and SSW., having a similar bearing to the 'Crag and Tail' and the 'Dressed Hummocks.' 'They are only slightly deflected while passing over hills some nearly 2,000 feet high, and seem to have been made by the movement of the Field, or Noppes, of ice that covered this country before the Boulder-drift Period.

The Secondary Stria always coincide with the fall of the ground, nearly every valley having a different system : they as often run across the 'Crag and Tail 'and 'Dressed Hummocks,' as not. They cut the Primary Striæ and often obliterate them, and are sometimes accompanied by grooves; but this is not often the case. They seem to have been formed when the Ice-sheet, or Nappes, was finally breaking up and sliding down the various hills and valleys.

I have observed Primary and Secondary Striæ in the following localities :-In the Valley of Galway, from Atheney to Golam Head; in the valley between the Burren Mountain, to Clare, and Slieve Aughta, from Gort to near Ennis; in the Ballynahinch Valley, from Oughterard to near Clifton ; in the valley in which Lough Corrib is now situated, from Maum to Kylebeg; in the valley now occupied by the Killeries; and in the various small valleys that occur among the hills in Jar-Connaught (christened by the English, Connemara)nearly every one of which has its own system of Secondary Striæ. They can also be well observed on the eastern slopes of Slieve Bawn (which rises as a 'Crag and Tail' in the plain about ten miles west of Longford), where the Primary Stria bear with the lie of the hill, while the Secondary Strix run down its slopes. That in none of the places that I have mentioned are the Strix due to local glaciation, is proved by their occurring under the Boulder-drift.

Oughterard, IreLAND: Aug. 19, 1865.

\section{J. Henry KinahaN.}

\section{DISCOVERY OF ERECT STEMS OF FOSSIL TREES IN TRAPPEAN ASH IN ARRAN.}

To the Editor of the Geological Magazine.

SIR,--The occurrence of beds of stratified trappean ash resting upon fossiliferous strata is not uncommon in the Coal-measures of the West of Scotland; but very rarely such beds are found to enclose organic remains, and hitherto, so far as I am aware, no beds have been found in situations where they can be studied and explored systematically.

'The north-eastern shores of Arran, exhibiting beautiful sections of the Carboniferous series, have been surveyed and described by various eminent geologists, and on their authority the beds of volcanic origin interstratified with the coal, shale, and sandstone of the series have been invariably accepted as either intercalated, or intrusive, trap-bcds, 'trap-dikes,' or 'outbursts of trap;' nor is it easy, on a mere cursory survey, to ascribe any other character to them.

A prolonged stay during the summer on these interesting shores has, however, enabled me to study these beds more minutely, and, on closer examination, the great majority of them are found to consist 